\title{
Earthquake-induced soft sediment deformation (SSD) structures from the Bilara limestone formation, Marwar basin, India
}

\author{
Partha Pratim Chakraborty ${ }^{1, *}$, Rajesh Sharma $^{2}$ and Pramod Kumar ${ }^{1}$ \\ ${ }^{1}$ Department of Geology, University of Delhi, Delhi 110 00\%, India. \\ ${ }^{2}$ Western Region, Geological Survey of India, Jaipur 302 004, India. \\ ${ }^{*}$ Corresponding author. e-mail: parthageology@gmail.com
}

MS received 25 September 2018; revised 2 March 2019; accepted 13 March 2019; published online 13 June 2019

The Neoproterozoic Bilara limestone Formation of the Marwar Group, Rajasthan, India exposes metresthick layers of soft sediment deformation (SSD) structures at different stratigraphic levels which could be traced over hundreds of metres on the outcrop scale. The SSD structures include disharmonic folds, lowangle thrusts, distorted laminae, fluidisation pipes, slump and load structures, homogeneities, diapirs, etc. Whereas SSD structures suggesting tensional stress, viz., intrastriatal graben, fluidisation, slump, etc. dominate in the lower part of the Bilara succession, features implicating compression, viz., folds, lowangle thrust are prevalent in the uppermost part. Since SSD structures are mostly confined within the algal laminites, we interpret that enhanced micritic fluid pressure below early cemented algal carbonate played a major role in laminae deformation. Depending on the degree of lithification and pore-water pressure, deformation features formed either plastically or led to diapiric injection at enhanced pore water pressure. Separated by near-horizontal underformed strata, the SSD layers, traceable over hundreds of metres, are interpreted as products of seismic shacking. Considering the time frame of the Marwar basin, i.e., the Precambrian-Cambrian transition, the SSD horizons present within the Bilara succession may hold the potential for the correlation with SSD structures reported from the time-correlative stratigraphic successions present in erstwhile adjoining tectonic terrains, e.g., China, Siberia, etc.

Keywords. Neoproterozoic; Bilara limestone; soft sediment deformation; seismite; micritic fluid pressure.

\section{Introduction}

Deformation/obliteration of primary stratification in the sediment column (clastic or carbonate) at the pre-diagenesis stage by means of fluidisation or liquefaction under the trigger of allogenic or autogenic forcing/s is referred to as 'soft sediment deformation (SSD)' and structures formed thereby are variously interpreted as signatures of palaeoseismicity, tectonic agility of a basin, unsteady palaeoslope, etc. Studies on SSDs are principally directed towards two lines of interpretation, viz., (i) deformation mechanism, viz., liquefaction, fluidisation, etc., and (ii) trigger causing the deformation, viz., earthquakes, pressure fluctuation due to a breaking wave or differential turbulence in the water flow, sediment loading and slope oversteepening or periglacial processes, including ground water seepage, etc. In rock records, SSDs are described as spanning over the geological time 
extending from the Precambrian to the Quaternary but less commonly from Precambrian successions (Sarkar et al. 1995; Bose et al. 1997; Chakraborty 2011). Most descriptions are from clastic rocks viz., sand and sandstones (Jones and Preston 1987; Van Loon 1992; Maltman 1994; Bose et al. 1997; Owen and Moretti 2011); descriptions from carbonates remained only limited (Ettensohn and Kulp 1995; Ettensohn et al. 2002b, 2011; Chakraborty 2011; Dechen and Aiping 2012; Sarkar et al. 2014). One major reason behind such limited SSD documentation from carbonate rocks is the extensive diagenetic alteration in carbonates that makes identification and characterisation of SSDs difficult, more so on freshly exposed sections.

Seilacher (1969) introduced the term 'seismite' to a suite of post-depositional soft-sediment deformation features having seismogenic origin. Since then, it is well established that seismicity is a factor of equal importance as current, wave or storm, etc., for sediment distribution and stratigraphic disposition not only in the craton-margin basins but also in the craton-interior basins, far removed from active margins (Obermeier et al. 1993, 2002). There is, however, no unequivocal single-feature indicator for seismicity in stratigraphic record since many causes can result in a similar deformation of sediments (Ricci Lucchi 1995). Whereas the cause and effect relationship between seismically triggered deformation features and active fault systems can be established with reasonable confidence in tectonically active basins, claims of seismites in stable cratonic basins and geologically old basins with partially preserved stratigraphic record often do not go unchallenged. In order to overcome the uncertainty, workers have relied on the integration of multiple criteria across a broad area as the most convincing argument in favour of the seismogenic origin of SSDs in geologically old cratonic basins (Wheeler 2002; Jewell and Ettensohn 2004).

In this backdrop, this study presents SSD structures, hitherto undescribed, from carbonates of late Neoproterozoic-early Cambrian Bilara group of the Marwar supergroup, Rajasthan. Irrespective of host lithology and facies type, SSD structures, formed in liquified, plastic and brittle states are noticed at different stratigraphic levels within the Bilara succession. The objectives of this contribution are (i) to characterise SSD structures including enigmatic bedding disruptions found in evenly bedded limestones from the microscopic to the outcrop scale and (ii) to infer the deformation mechanism and the nature of the trigger.

\section{Marwar geology}

The late Neoproterozoic-early Cambrian sediments of the basin, covering a vast area on the Rajasthan shelf, represents the westerly dipping eastern flank of the Indus shelf of the Indo-Arabian geological province (Shrivatava 1992; Pandey and Bahadur 2009) (figure 2). On the basis of litho- and chemostratigraphy, Huqf supergroup, Oman with Khewra, Kussak and Jutana Formations of the Salt range and the Marwar Supergroup of western Rajasthan are correlated. Hosted within the Aravalli craton and the overlying 700 Ma-old (681-771 Ma; Torsvik et al. 2001; Gregory et al. 2009) Malani igneous suite (MIS) of rocks, the sedimentary succession of the Marwar supergroup is subdivided into the lower Jodhpur Group, middle Bilara Group and the upper Nagaur Group (figure 1; Pareek 1984; Chauhan et al. 2004). Whereas the Jodhpur and Nagaur Groups are siliciclastic, carbonates dominate the middle Bilara Group. Except for the Sonia sandstone Formation of the Jodhpur group, the Marwar Supergroup of rocks still awaits a process-based environmental analysis. On the basis of lithology and trace fossil characters, Pandey and Bahadur (2009) suggested glacio-fluvial, lagoonal and shallow marine deposition at varying depths and salinity for different stratigraphic intervals of the Marwar supergroup. From process-based facies analyses, Sarkar et al. (2014) interpreted the deposition of the Sonia sandstone Formation in a braided fluvial to wavedominated shallow marine setting. Samanta et al. (2011) documented an exquisite array of microbialmat induced sedimentary structures (MISS) from the Sonia sandstone Formation.

A couple of studies attempted age-bracketing the Marwar supergroup between late Neoproterozoic and early Palaeozoic. From putative trilobite traces within the Nagaur Group, Kumar and Pandey (2008) ascertained the Palaeozoic time frame. McKenzie et al. (2011) estimated La-ICPMS detrital zircon maximum age $\sim 540 \mathrm{Ma}$ for sandstones of the Nagaur formation. On the basis of the ${ }^{87} \mathrm{Sr} /{ }^{86} \mathrm{Sr}$ and $\mathrm{Ca} / \mathrm{Sr}$ values, Ansari et al. (2018) inferred the probable age of the Gotan limestone of the Bilara Formation as 520-530 and $570 \mathrm{Ma}$, respectively. Chauhan (1999) proposed an intracratonic rift/sag model for the basin. From the appreciation of tectonics and thermal events of NW Rajasthan, Meert et al. (2010) argued that the Marwar basin evolved as an intracratonic asymmetric basin with a westward tilt by the 

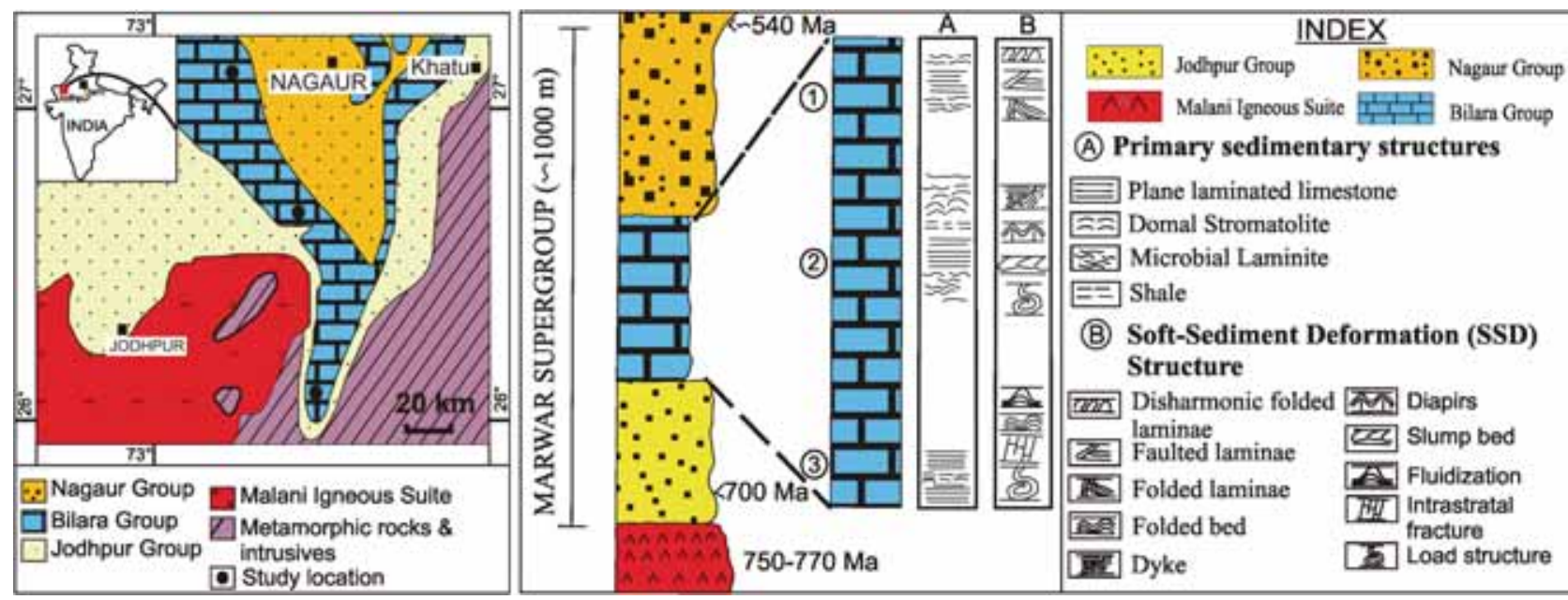

Figure 1. Map of the Bilara group, Marwar supergroup with locations (bold black dots) of studied sections. Stratigraphic subdivisions of the Marwar supergroup and primary, secondary deformation structures documented from three different stratigraphic levels of the Bilara group are shown on the right.

reactivation of the NNE-SSW lineaments of the Archaean and early Proterozoic age.

\subsection{Bilara limestone (BL) Formation}

The Bilara succession largely made up of subtidal to peritidal limestone, separated intermittently by silty shale. Stromatolites with wavy, irregular laminated sheets, low-relief domes or partially linked, microdigitate columns, algal laminites, intraclastic limestone, thick-bedded dolosiltite-thin-bedded calcilutite alternation and dark grey/black fissile shale comprise the Bilara Group and subdivided under three formations, viz., Dhanapa, Gotan and Pondlu, in order of superposition. The degree of secondary alteration, in particular, dolomitisation and chertification, is considered as the basis for classification. Major facies constituents of the Bilara limestone classified on the basis of lithology and primary sedimentary structure. Table 1 summarises facies types, their geometry, internal structure and plausible hydrodynamic/bathymetric control on deposition. Alternation between wavy and crinkly algal microlaminite and microdigitate, synoptic relief stromatolites with preserved 'teepe' structure is identified as a product of stratiform, benthic microbial mat growth in an intertidal to a shallow subtidal setting (Grotzinger 1989; Pratt et al. 1992; Sarkar and Bose 1992; Sarkar et al. 1996). In these environments, laminites commonly record a combination of precipitation of fine-grained carbonate and trapping of detrital sediment with benthic microbial mats (Grotzinger 1986; Hamon and Merzeraud 2008). Working on modern stromatolites of the Shark bay, Australia,
Hoffman (1976) concluded that stromatolite morphology in any environment depends heavily on operative physical processes; smaller stromatolites and sheet-like cryptalgal laminites develop in the settings of low stress, where biotic processes dominate algal morphology. In contrast, large stromatolites with impressive morphologies form in high-stress environments, irrespective of shallow or deep water. Indeed, large stromatolites, often with cabbage-headed morphology, are described from both subtidal (Dill et al. 1986) and shallow peritidal (Wilks 1986) settings. The occurrence of large, domal-headed stromatolites is noticed within the Bilara succession as parts of both shallowing- and deepening-upward parasequence/s. A combination of factors including benthic microbial communities, sea floor cement precipitation and settling of carbonate mud from the water column is interpreted for the development of tidal flat tuffas as part of BL depositional hemicycles.

Variably thick (centimetres to metres in thickness) tabular, monotonous deep water carbonate mudstone, either in amalgamation or separated by silty shale interbeds and with no evidence of nearby shallow-water carbonate environment, e.g., desiccation crack, etc., are interpreted as products of spontaneous precipitation in a subtidal carbonate factory with a high level of saturation prior to the evolutionary appearance of carbonate-precipitating skeletal benthos in the early Palaeozoic era (James and Jones 2016).

The SSDs described belong to the stromatolitic and plane-laminated limestone facies, i.e., facies types Lst1 and Lst2 (table 1) belonging to the 
Table 1. Facies types from the Bilara limestone formation with their field features, primary structures and petrological characters.

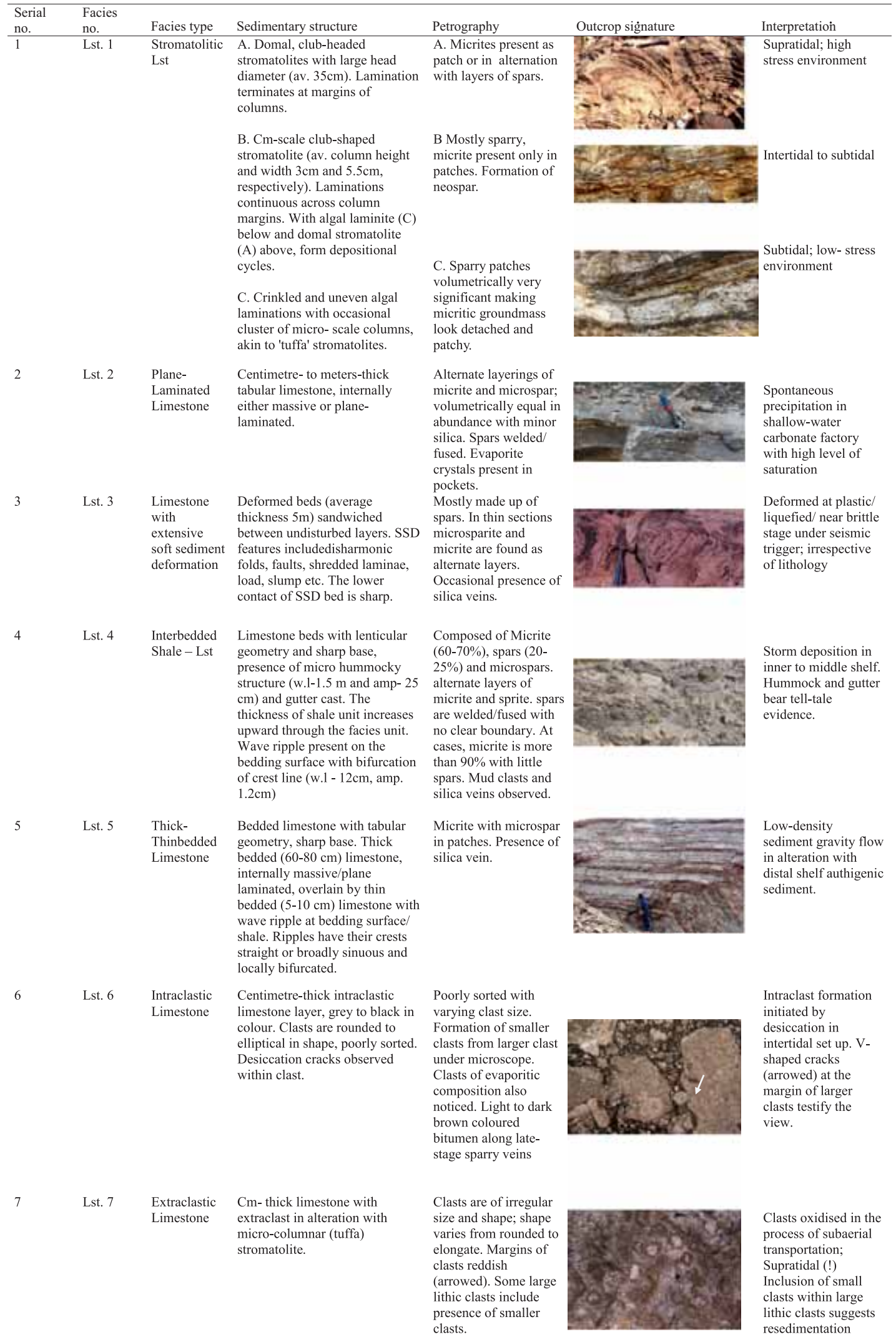



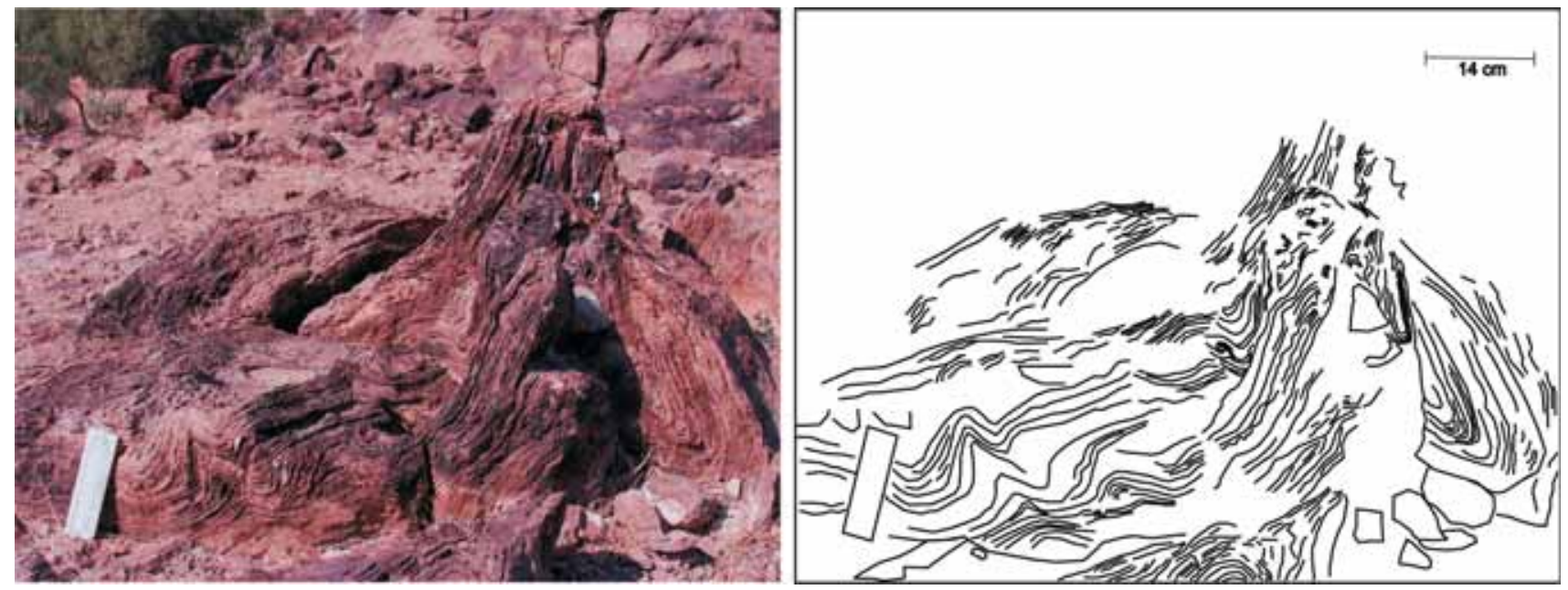

Figure 2. Disharmonically folded algal laminite. Sketch alongside showing the irregular character of folds varying from symmetric to asymmetric.

Dhandpa and Pondlu Formations of the BL. The Dhandpa Formation SSD structures are documented from metres-thick bedded lithographic limestone exposed in mine sections near the Bilara village (Chamunda Devi section) and Rajasthan State Mine Section (RSMS) near Dhandpa village. The SSD structures belonging to the Pondlu Formation are documented from algal laminite limestones exposed in a hillock section near the village Gopa in the north-western part of the basin.

\section{SSD structures}

SSD structures in the BL are present with widely varying morphologies and hence, presented in a large number of descriptive terms. Since there is no general acceptance of a single classification for soft-sediment deformation and resulting structures (Owen and Moretti 2011), categorisation and description of SSD features is done on the basis of morphology and deformation style of structures, which, of course, depends on the nature of sediment rheology, triggering force and deformation mechanism. Broadly, the structures are divided under two rheological states, viz., (i) structures formed in a liquefied/plastic state and (ii) structures formed in a near-brittle state. Whereas some structures described herein involve a number of beds, others are bed-confined.

\subsection{SSDs formed in the plastic or liquified state}

\subsubsection{Disharmonic folded laminites}

A cryptalgal laminite layer of average thickness $2.25 \mathrm{~m}$ shows persistent contortion of internal laminations and formation of alternate antiforms and synforms (wavelength and height varying from 8 to 19 and 11-24 cm; respectively) with highly irregular geometry (figure 2). Top surfaces of the unit is planar, but the base is not always so. In fact, no discernible break is noticed at the contact of this unit with underlying undisturbed strata. The folds are close to tight and their geometry varies from symmetric to asymmetric. Folding style changes from regular (i.e., similar geometry in adjacent folds) to chaotic within the exposure length. Their axes are sub-horizontal, nearly parallel to bedding. The interlimb angle of antiforms widely varies; a variation from $30^{\circ}$ to $45^{\circ}$ can be noticed within a single antiform from its core outward. In cases, laminites involved in antiform do not maintain uniform inclination and show a truncational relationship with adjacent laminae. Detachment along the axial plane of the antiform is also not uncommon. Occasionally, the alignment of fluidised material can be seen as extruding vein coincident with axes of tight antiforms. Within synforms, the disruption of laminae and homogenisation is a common observation. In some cases, the folds also assume chevron geometry with one limb near the horizontal and the other near the sub-vertical and thereby create an interlimb angle $>60^{\circ}$. Hinge areas of these folds show clear evidence of fluidisation and laminae disruption. Laterally, centres of intense deformation with complete sediment homogenisation are found surrounded by roughly concentric less deformed laminae (figure 3).

Interpretation: The disharmonic and chaotic nature of folds without any regular geometry of fold orientation and distribution bear clear indication of the penecontemporaneous origin of these 
structures. Near horizontal algal lamination in encasing sediment succession and uniform sedimentary condition traceable over $\sim 250$ m of outcrop width rules out any gravity effect in the generation of these structures including slump-related origin. Instead, intense deformation confined within unreformed sediment succession points towards an increase in pore fluid pressure and velocity, resulting in energy release and intense deformation (cf. Holzer et al. 1989; Ettensohn et al. 2011). Introducing the concept of 'minimum fluidisation velocity $\left(U_{0}\right)^{\prime}$, Lowe (1975) correlated SSD intensity with released energy and concomitant pore fluid velocity. Disharmonic folds and bed contortions with preserved primary algal lamination and negligible fluid flow are interpreted as a result of low-energy hydroplastic deformation at a pore fluid velocity well below $U_{0}$. Laterally, with the increase in pore-fluid velocity reaching near $U_{0}$, liquefaction becomes intense and results in homogenisation with the near destruction of primary lamination. The presence of different scales

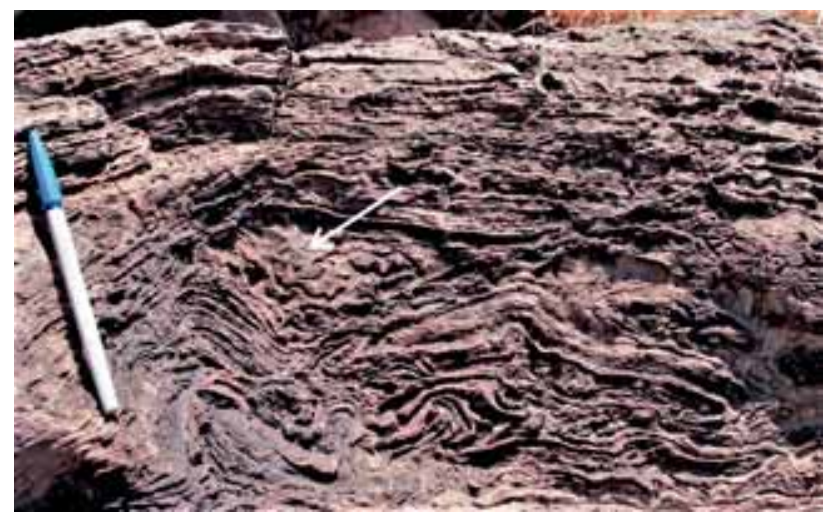

Figure 3. Intense SSD in algal laminites: near complete sediment homogenisation (arrowed) surrounded by roughly concentric decreasing-energy deformed laminae. of deformation structures in a single section of $\sim 250 \mathrm{~m}$ width suggests spatially variable energy input in a uniform lithology that caused different pore-fluid pressures. Mapping of such varied character deformation features over well-constrained horizons may lead to the identification of point source of energy input expected in seismicityinduced SSD (Reiter 1990).

\subsubsection{Coherent slumps and apparent load structures}

A $\sim 10$ m quarry section at the RSMS represents the occurrence of mudstone, stromatolitic biostrome and dark-coloured algal laminated limestone, in alternation. Laterally persistent undulations at the interface between dark-coloured, near-horizontal algal laminated limestone and underlying buff-coloured slumped stromatolite biostrome (figure 4) demarcate the slump-triggered load structures. Within slumped stromatolite biostrome, laminae are weak to moderately deform in the form of continuous centimetre-scale folds. Folds are conserved just above the underlying mud layer and the entire biostrome presumes the shape of a series of rounded spheroidal lobes. Within the slumped lobes, folds are largely cylindrical and their vergence varies widely and continuously. Algal laminations bend around parallel to the morphometry formed by the underlying slumps and are observed to thicken and thin assuming load geometries; sometimes in curves between two successive slumped lobes. However, the contact between the biostrome and algal lamination is always sharp. However, upward from the interface, the degree of undulation decreases. The average wavelength and height of undulation formed in algal lamination is 20 and $35 \mathrm{~cm}$, respectively.
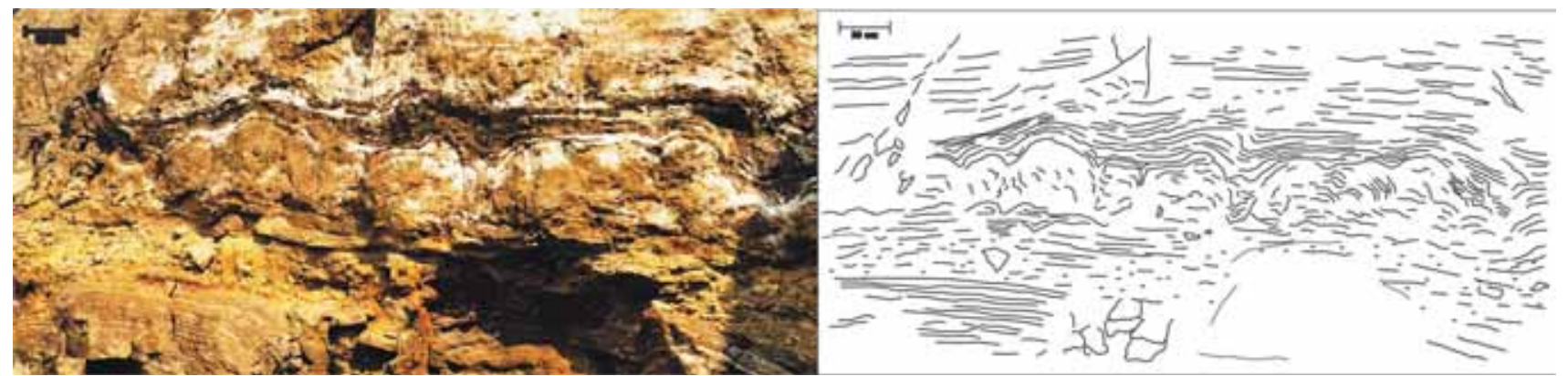

Figure 4. Photograph and sketch showing the formation of coherent slump lobe and apparent load structure. Note the presence of mudstone below the slumped layer. Rotation of laminae within a slump lobe shown in the inset. 
Interpretation: Slumped units overlying mud layers are commonly interpreted (Strachan 2002; GarciaTortosa et al. 2011) as a result of mud fluidisation and weakening. Sharp truncation at the top of the slumped layer suggests that the slumped strata formed at the sediment-water interface. Since the slump structures are considered to have been exposed at the sediment surface at the time of deformation, it can be argued that the slumping was not overpressure-triggered because of liquidisation/fluidisation under an overburden. The slumped strata possibly resulted from the hydroplastic deformation associated with slope failure. Possibly the $\sim 5$-cm thick underlying mud layer acted as a weak decollement (Alsop and Marco 2013). Depending on lithology, seismically triggered slumping is documented from slopes as low as $0.25^{\circ}$ for earthquake magnitude $>5.5$ (Spence and Tucker 1997; Ettensohn et al. 2002a). Alternatively, load structures are also described as a result of the vertical displacement triggered by gravitational forces associated with reverse density (Owen 2003; Owen and Moretti 2011). However, in the present case, loading of dark-coloured algal laminations mimicking the geometry of the underlying slump lobes rules out any reverse density effect; instead apparent load structures are interpreted as products of passive growth of algal laminations on the available undulatory surface of the slumped layer.

\subsubsection{Incoherent slumps and homogeneities}

A decimetre-thick layer, made up of disturbed stromatolite columns and intraclasts, represents slump structures. Stromatolite columns loaded within the underlying carbonate mudstone and/or showing evidence of lamination obliteration because of fluidisation and homogenisation (figure 5), stromatolites and algal laminites moulded in the form of complicated folds, at times with recumbent geometry (figure 5) or brecciated in the form of intraclasts represent this unit. Folding can be seen even in the small scale of laminite without any evidence of subsequent flattening. The thickness of these units varies from 0.15 to $0.27 \mathrm{~m}$. The dewatering phase, contemporaneous with the formation of slump, is evident in the presence of homogenised calcarenite/calcirudite dyke cutting across algal lamination.

Interpretation: Encased between horizontally laminated carbonate, folded laminations with widely varying geometry resemble slump structures (millimetres to decimetres thick) described from depositional environments devoid of any significant slope. Such slump structures, formed by the liquefaction of well-laminated sediments, are used as earthquake indicators (Marco 1996) and reported from lacustrine and marine settings (Hempton and Dewey 1983; Ringrose 1989). A common association is noticed between seismo-slumps and levels totally devoid of lamination (homogeneities; Rodríguez-Pascua et al. 2000). The obliteration of pre-existent depositional structures, viz., bedding, lamination, etc. bear clear indication of prelithification deformation in the sediment column to generate slump structures (Elliot and Williams 1988).

\subsubsection{Diapir sand dykes}

Extrusive bodies in the form of both diapir and dyke are present at different stratigraphic levels within the Bilara succession. Diapirs, constituted of both lime mudstone and micritic carbonate, are up to $15 \mathrm{~cm}$ high and $\sim 4.5 \mathrm{~cm}$ wide found up warping single laminae or lamina set/s in the overlying strata depending on homogeneity and consistency of laminations (figure 6). They usually are dome shaped and are somewhat distributed non-uniformly. Dykes are vertical bodies, cut across
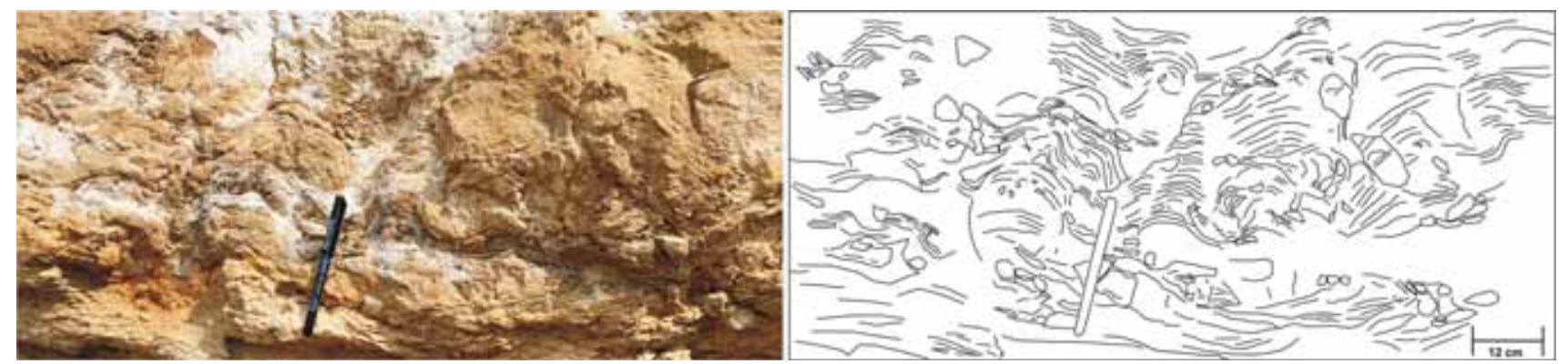

Figure 5. Incoherent slumps involving stromatolites. Sketch alongside showing detachment, bending and rolling of laminae, laterally either getting homogenised or forming intraclasts. 

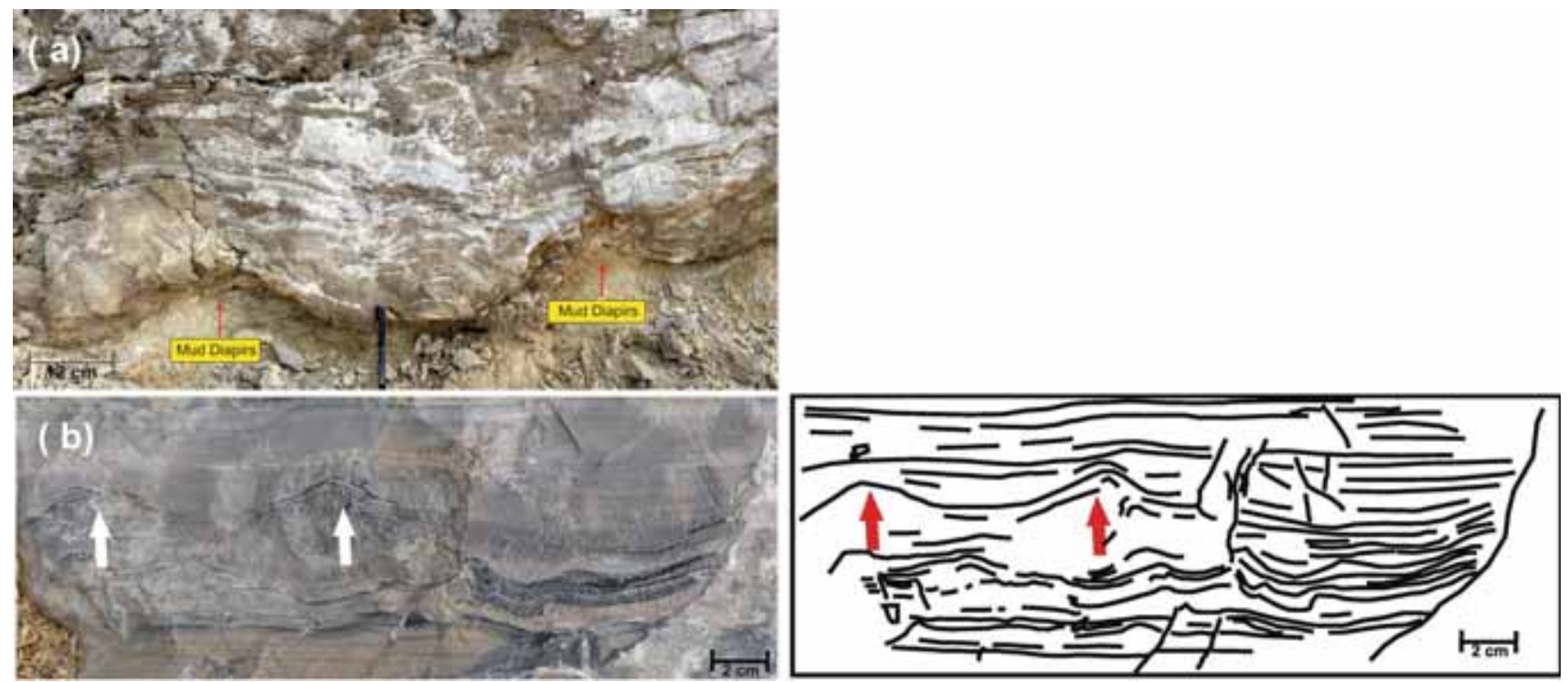

Figure 6. Liquefaction diapirs of mud (a) and carbonate (b). Sketch alongside demonstrates intrastriatal liquefaction and diapir formation.
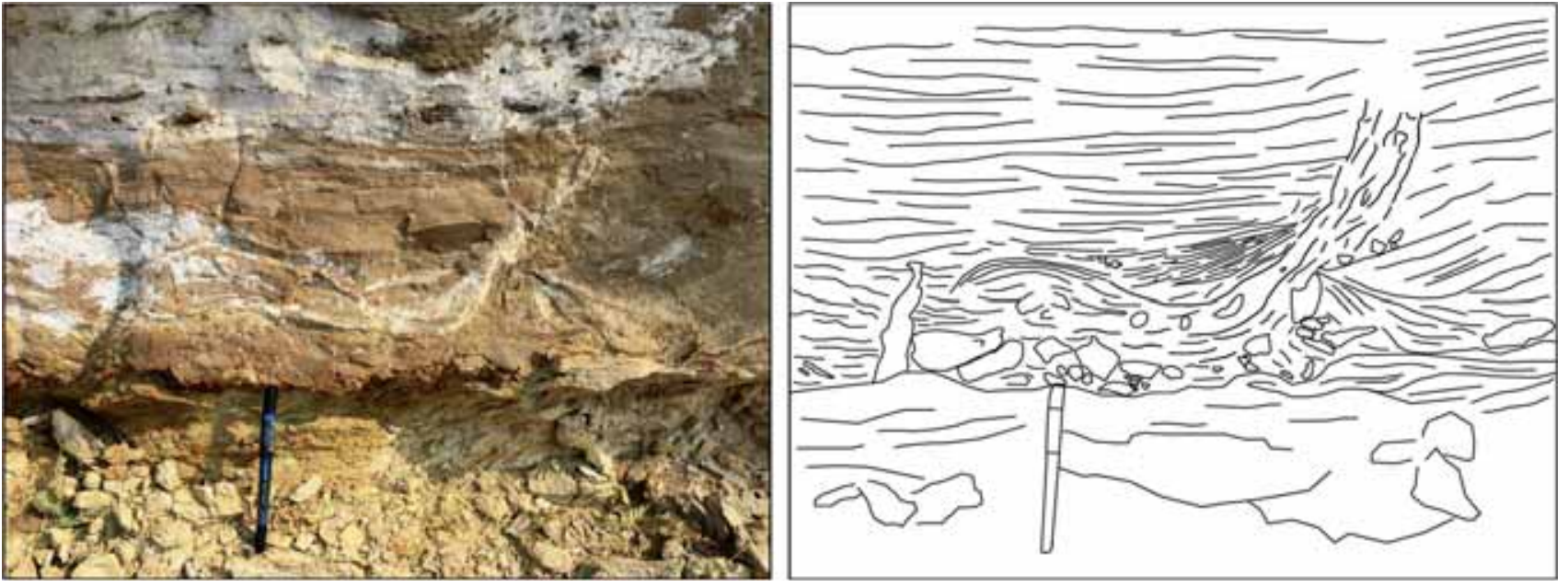

Figure 7. Injection dyke; field photograph and sketch. Note intraclast formation and their incorporation within extrusive material.

laminations and filled by fluidised and homogenised sediment, i.e., coarse calcarenite or micritic limestone (injection dykes). In some cases, dykes are found associated with the layer marked by intrastriatal fracture and intraclast formation (figure 7). The intraclast fragments are all angular, and vary several millimetres to over $2.3 \mathrm{~cm}$ in length. Along with homogeneous medium- to coarse-grained carbonate sand grains, carbonate lithic fragments are also found as dyke fill.

Interpretation: The extrusive nature of diapir and dike becomes clear either from upwarping of overlying strata or upward bending of confining layers.
Carbonate rocks become cemented much faster than siliciclastic rocks. In the case of any shock and vibration, carbonate mudstone, being uncemented at that time tend to become plastic with increased pore water pressure, move upward and thereby form a diapir. Since the observed dyke is found in association with the intraclastic layer, it is presumed that the intraclasts were formed by the hydrofracturing by overpressured water because of fluidisation. Workers have also described the formation of similar carbonate intraclasts as products of autoclastic brecciation (Montenat et al. 2007), slide and slump (Sarkar et al. 2014) or spring sapping and evaporation dissolution (Sarkar et al. 

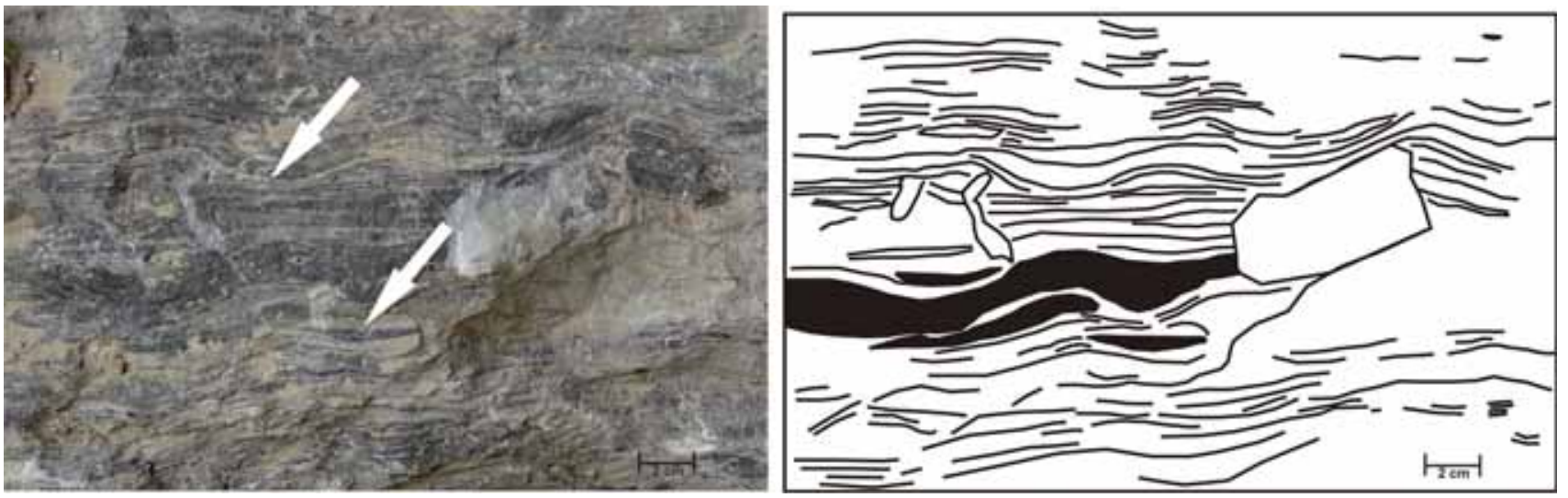

Figure 8. Photograph showing concave-up slide scar (arrowed) and loading vis-à-vis the sinking of detached carbonate laminae within the underlying mudstone (arrowed). A sketch is given alongside for the illustration of features.

1994). The uprise of overpressured (fluidised) soft sediment along fractures caused the formation of injection dyke, filled with fluidised sediment and intraclasts.

\subsubsection{Chaotically associated structures}

The chaotic association of diverse structures resulting from fluidisation, fluid expulsion, loading and sliding characterises these penecontemporaneously deformed layers. The maximum thickness of these layers is $10 \mathrm{~cm}$. Encased between the near horizontal-laminated strata, carbonate lamina sets show broad undulatory character in synchronicity with the uprising mud layer. From lateral thinning and thickening without losing lateral geometrical continuity, the laminae sets also show detachment with extreme lenticularity in detached fragments. The thickness of the disturbed laminae ranges from 0.2 to $0.5 \mathrm{~cm}$. With a higher degree of loading, the laminae set detached and isolated from the bottom part of the carbonate layer and enclosed as lenticular limestone pod/s within the underlying mud (figure 8). Furthermore, with differential liquefaction and rheological behaviour of carbonate and mudstone, a number of bizarre structures are formed on the centimetreto decimetre scale with varied contortion of carbonate laminae sets (figure 9). These include crumpled laminae, shraded laminae, rolled-up laminae, saucer-shaped laminae, sagged and inclined laminae, etc. Intermittent concave-up erosional surfaces with a maximum relief of $3.5 \mathrm{~cm}$ are found truncating both carbonate and mudstone layer (figure 8). The top of the deformed layer is overlain sharply by the horizontally laminated sediment.

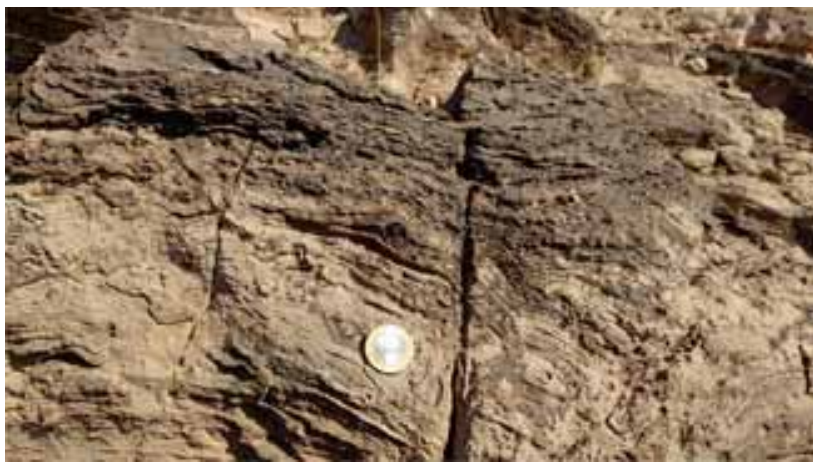

Figure 9. Liquefaction and wild contortions of laminae. Note the liquefied unit is bounded between undisturbed strata.

Under a microscope, these layers show evidences of block shattering with highly crumpled, disordered and faulted lamination (figure 10a and b). Step-wise faulting of lamination can also be observed. Shattered fragments with randomly oriented laminations made up of single and/or sets of laminites are millimetres to centimetres long (figure 10c). Microscopic observation from the folded part reveals the occurrence of folded vein within micritic groundmass (figure 10d).

Interpretation: The evident liquefaction might have been induced on the depositional surface by density inversion (Allen 1982). An alteration between mudstone and laminated limestone, at times algal, seems to have facilitated the development of multifarious features. An advanced stage of liquefaction might have led to fluidisation in the mud layer and thixotropic behaviour in carbonate layers to result in the formation of a lenticular, pod-shaped load structure. Additionally, a wide spectrum of bizarre structures including crumpled, shraded, rolled-up or sagged laminae, grading into each other on the 

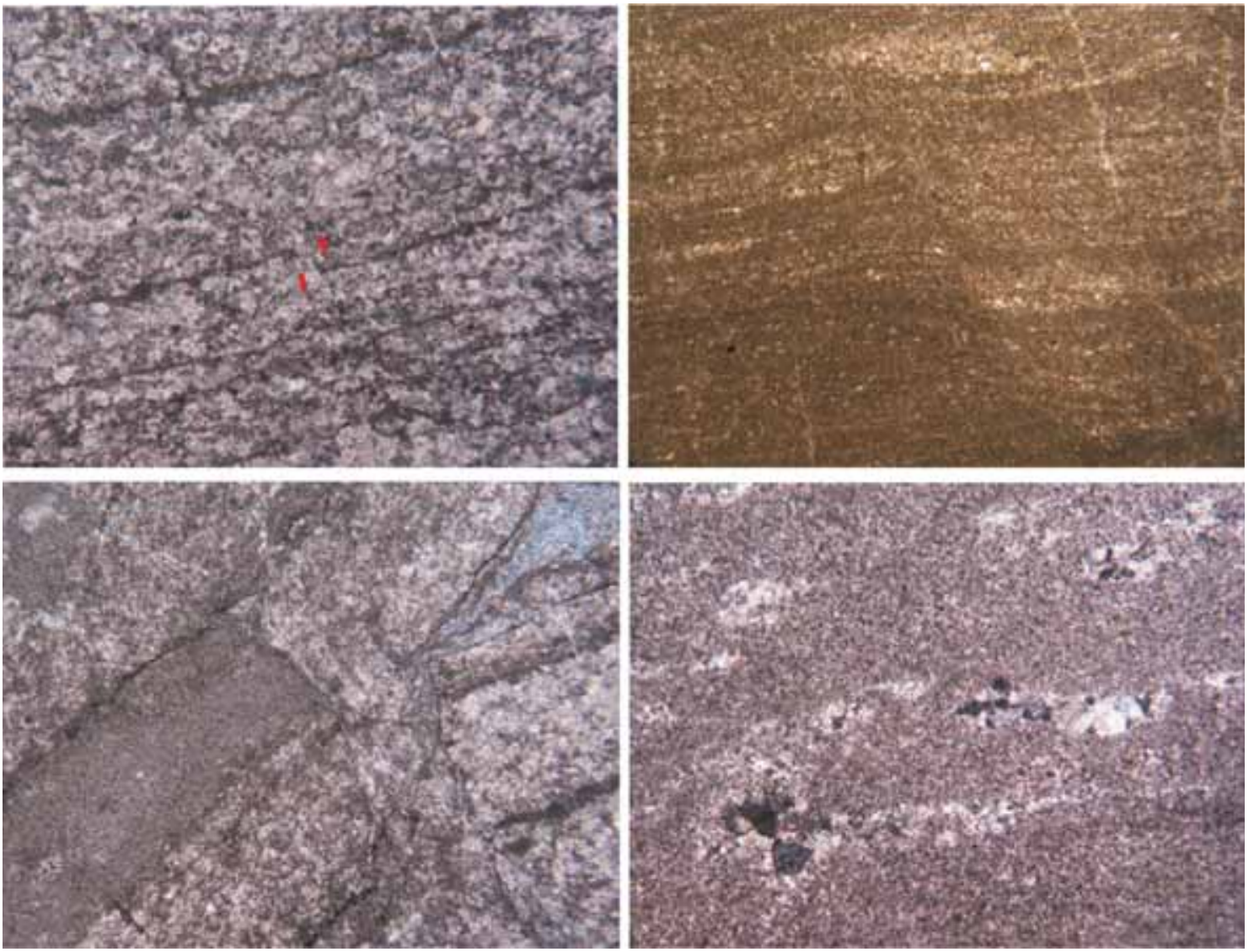

Figure 10. Photomicrographs of offset laminae with (a) downslope movement, (b) upslope movement; bending of host laminae, (c) intraclast and (d) folded vein.

outcrop scale, bear an indication of the varying rheological behaviour within individual beds, may be because of the variation in the pre-deformation physical state, i.e., lithification, mineralogical composition, etc. Such variation may result in equally variable second-order properties, viz., fluid saturation, shear strength, etc. With different degrees of liquefaction (partial to complete), structures varied widely ranging from ductile deformation with the preservation of stratification to obliteration of stratification with complete liquefaction (cf. Heubeck et al. 2013).

\subsection{SSDs formed in the near-brittle state}

\subsubsection{Intrastriatal fracture}

Intrastriatal fractures represent principle SSD structures formed in brittle deformation. With a maximum vertical extent of $12.5 \mathrm{~cm}$, these faults, either in isolation or as a pair, show displacement of strata ranging from 0.12 to $0.36 \mathrm{~cm}$. The spacing between the fractures is, on average, $4.5 \mathrm{~cm}$. At times, a pair of normal faults converge downward to form a graben geometry. Figure 11 illustrates sets of intrastriatal fracture with or without offsetting the lamination. The laminae on the hanging walls show either a minor wrinkling or a slight thickening towards the fracture plain. Extension of fractures on the vertical plane could be traced from the centimetres to the decimetre scale before they die out. At times, fracture set with step-like laminae dislocation could also be traced (figure 10). Deformation of laminae in the form of an overturned fold could be traced within a block bounded between fractures. Local liquefaction along the fracture plane is not uncommon.

Interpretation: Fractures must have formed at the sediment-water interface as is evident in their mantling by the undisturbed sediment package. Because of early lithification and hardening, limestones often behave in a brittle manner. Offsetting, bending and thickening of laminae near the fracture plane and dying out of the fracture plane in a short aerial extent bear indication 

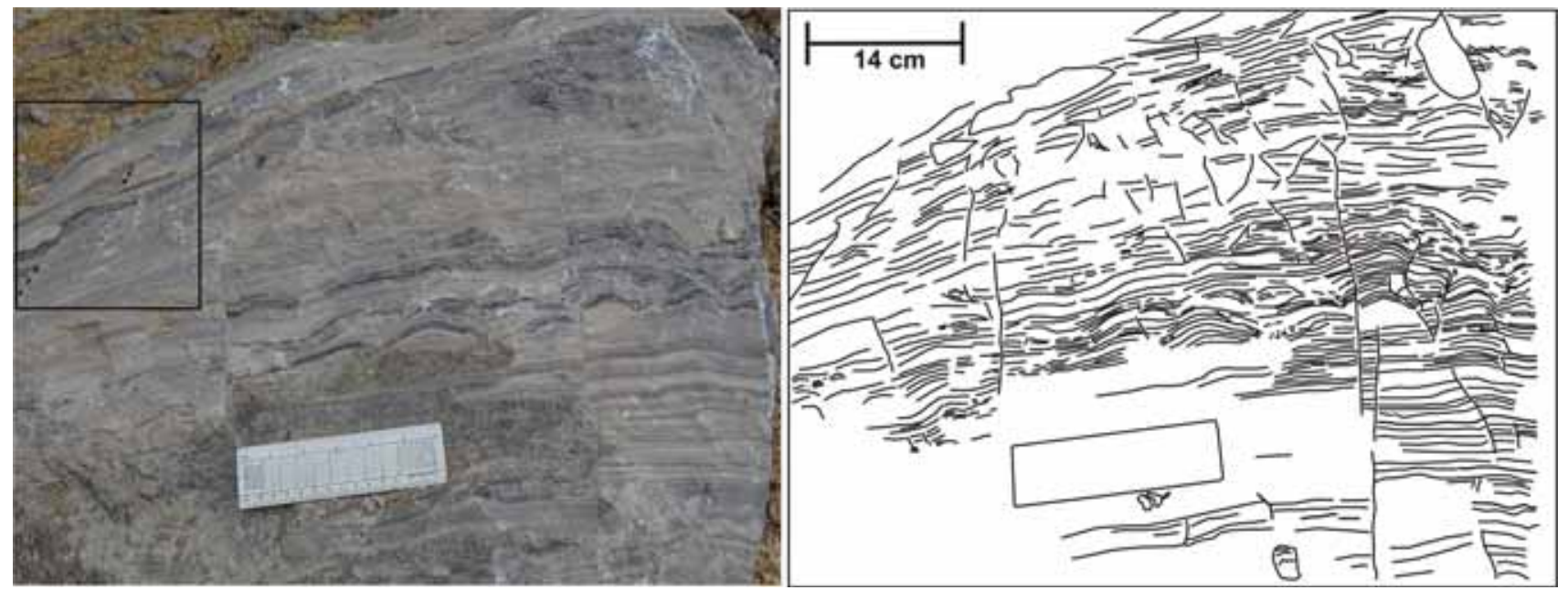

Figure 11. Sets of intrastriatal fracture; step-wise normal fault on the left top (marked and enboxed). Note offsetting of laminae, occasional deformation of laminae bounded between the fractures and liquefaction near the fracture.
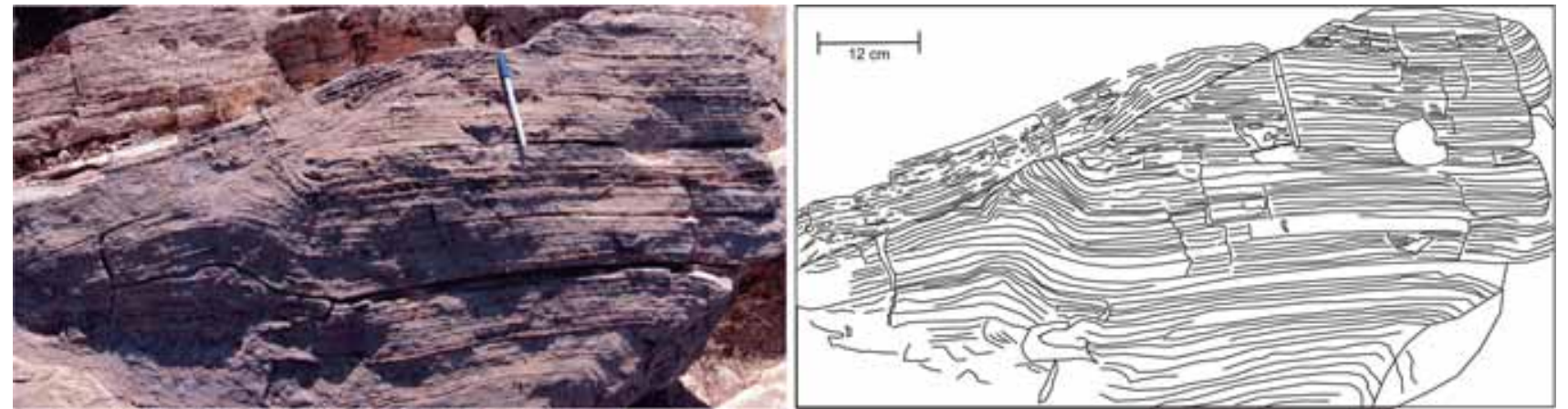

Figure 12. Low-angle intrastriatal thrust. Note the bending of laminae and liquefaction below the thrust plane. Also note low-angle truncation within the thrust sheet. Sketch alongside to highlight features within and below the thrust sheet.

for the syn-sedimentary origin of these fractures (Bose et al. 1997). A high angle of fractures and laminae offset indicating hanging a block movement down the fracture plane slope bears indication of generation of fracture sets in an extensional domain. Step-wise offset of laminae also corroborate the contention.

\subsubsection{Syn-sedimentary low-angle thrust}

A low angle $\left(<25^{\circ}\right)$ truncation plane with definite angular discordance between laminations of underand overlying-strata represent the thrust planes (figure 10). While laminations within the overlying block conform to the thrust plane, laminites in the underlying block form an acute to an obtuse angle with the truncation plane. Near the truncation plane, fluidisation and steepening of laminae are common observations within the underlying block. Besides, contortion, disruption, shrading of laminae and finally leading to complete fluidisation and massiveness are noticed in the underlying block along the truncation surface. Within the overlying block, two worth-mentioning features are (i) laterally discontinuous low-angle curved truncation plane punctuating the laminite package and (ii) rotation of laminae in the frontal part to form a fold-like structure. Evidences of thrusting and concomitant bending of laminae are also seen under the microscope (figure 12).

Interpretation: Thrust involving algal-laminated limestone bear indication of the near brittle deformation, which might be facilitated by early lithification in carbonate lithologies at the sea floor or in a very shallow burial (less than few tens of centimetres) environment. Non-uniform cementation in carbonate may generate considerable compositional anisotropy between cemented and uncemented parts and enhance the possibility of an intrastriatal slip either parallel or at a low angle to the bedding (Chen et al. 2009). With the introduction of body force at a high rate of stress, partially lithified carbonate beds may yield in a 
brittle manner (Erickson et al. 2001; Evans and Bradbury 2007). The high angle bending of laminae and liquefaction in the underlying block of the thrust plane reflect the drag at the front of the thrust sheet as it moved up the failure surface. Also, internal deformations within the thrust sheet suggest variable rheological behaviour at the time of thrusting. The presence of ragged laminae and a fold-like structure at the leading edge of the thrust sheet bear the signature of both brittle and ductile characteristics. Local stresses associated with the thrusting possibly applied parallel to horizontal laminae and thrust plane formed at $\sim 20^{\circ}$ to bedding (Peacock and Sanderson 1992).

\section{Discussion}

The differentiation of synsedimentary from tectonic deformation relies on criteria that establish temporal limitations for the timing of deformation. Whereas features, e.g., deformed fossils, foliation-controlled mineralisation, etc., help in the demarcation of pervasive tectonic deformation, postdated bores, burrowings and organic encrustrations help in the identification of syn-sediment ary (soft) sediment deformations (Coniglio 1986). Features that helped in the interpretation of deformation features within the Bilara Formation as syn-sedimentary in origin include: (i) typically chaotic, laterally discontinuous, opposing structures; (ii) the separation of deformed horizons by undeformed strata (figure 13); (iii) the absence of any deformation fabric, e.g., axial plane cleavage; (iv) the absence of vein- or joint-related to any deformation fabric (cf. Hobbs et al. 1976) and (v) the absence of any feature (structural/tectonic) indicating solid-body deformation of carbonates in high-strain zones, e.g., pressure solution seams, calcite veining, slickensides, fault damage zones, etc.

Carbonate systems during the Precambrian era were dominated by microbes and associated organic molecules (James and Jones 2016). Depending upon the microbe variety, biofilms are formed either as cohesive gel or loose slime, made up of extracellular polysaccharides (EPS) and act as nucleation centres for carbonate precipitation. In contrast to such cohesive microbial carbonate sheaths, mudstones are clastic and less cohesive. This difference in lithology and cohesiveness possibly played a major role in the penecontemporaneous deformation pattern of the Bilara limestone. In the case of lithology being uniform and made up solely of algal laminite, sediments behaved in a uniform plastic manner or brittle manner without much effect of liquefaction and fluidisation. Algal laminites tend to lithify at various scales penecontemporaneously with deposition and hence, act fast enough to seal intervening, water-saturated micritic laminae (Ettensohn et al. 2011). Depending on the scale of lithification, localised accumulation of micritic fluid and pore-water pressure, deformation features formed either plastically or in a brittle manner. Working on deep-lacustrine cohesive diatomrich laminites, Grimm and Orange (1997) showed that for any mechanical deformation the high shear strength laminites behave mostly in a brittle/plastic way. This is exemplified in the Gopa section where algal laminated limestone responded in the form of disharmonic folds and low angle thrusts in response to shock/s. In contrast, the Chamunda Devi and RSMS sections where alteration between algal laminite/stromatolitic biostrome and mudstone represent the dominant lithology,

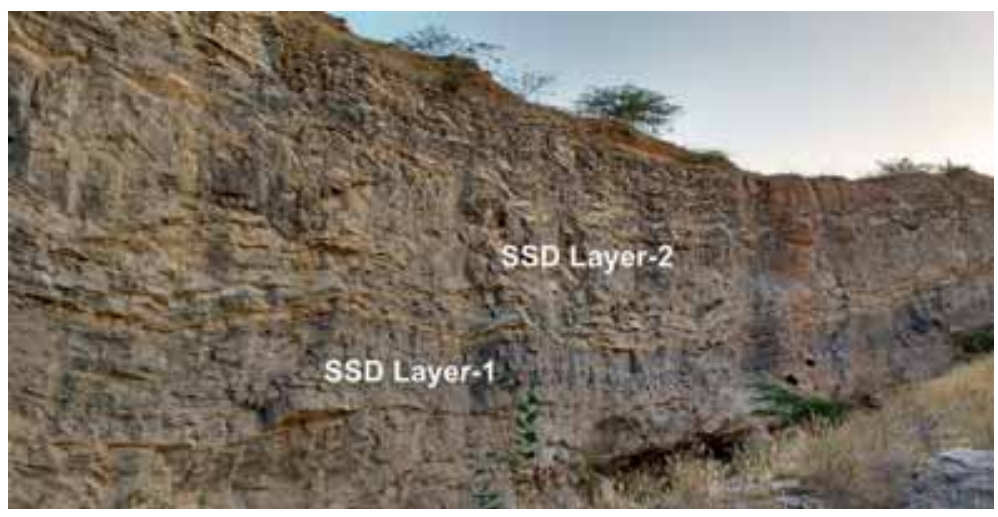

Figure 13. Panoramic view from the Chamunda Devi mine section showing lateral continuity of soft sediment deformed layers, underlain and overlain by undisturbed strata. 
deformation is more guided by the liquefaction/ fluidisation of mud and the thixotropic behaviour of limestone; limestone units often reacted only in a passive manner in the form of loading, slumping, shrading, etc. Diapirs and synsedimentary dykes in association confirm the contention.

\subsection{Nature of trigger}

$\mathrm{SSD}$ is not a unique response for any possible trigger. Keeping this in mind, workers have highlighted two aspects of trigger behind SSD formation, e.g., (i) deformation mechanism and (ii) trigger for deformation mechanism (Owen and Moretti 2011; Owen et al. 2011). It is argued that triggers for deformation may either be external (allogenic/exogenic including earthquakes) or underpinned by processes operative in any depositional environment (autogenic/endogenic; rapid sedimentation, periodic thawing, floods, storms, etc.). Since endogenic triggers are linked to the depositional environment, it becomes crucial to establish connectivity between sedimentary facies and SSD to be justified. Amongst exogenic factors, seismicity is commonly projected as a causative factor but often falls short of supporting evidence. Equivocal criteria that suggest seismicity as a causative trigger include (i) deformation with a widespread distribution, (ii) deformation that can be temporally or stratigraphically constrained and (iii) deformation with a systematic increase in frequency, size and intensity towards a likely epicentral area.

Separated by undeformed sediments, the occurrence of SSDs as laterally continuous stratigraphic intervals within the intertidal/shallow peritidal stromatolitic and plane laminated limestones of Bilara succession rules out any endogenic trigger, viz., evaporate dissolution, unstable density gradient, etc., and allows the proposition of exogenic trigger e.g., seismic shock. Indeed, seismites in shallow lake deposits are interpreted as a result of the reduction in natural shear strength of less cohesive coarse-grained sediments by liquefaction. In comparison, cohesive laminites/varve-like sequences require earthquake magnitude $\geq 5$ for liquefaction (Rodríguez-Pascua et al. 2000). Mixed layers comprising fluidised sediments in varvelike laminites giving rise to mushroom-like structures are interpreted as products of earthquake magnitude of at least M5.5 (Hempton and Dewey 1983; Marco and Agnon 1995). A limit value of earthquake magnitude 5 is proposed by
Rodríguez-Pascua et al. (2000) to distinguish seismites involving the folding and/or fracturing of laminites under brittle or ductile condition $(M \geq 5)$ from those showing evidence of liquefaction. In this backdrop, disharmonic but intricately folded and thrusted algal laminites at the Gopa section suggest deformation at a reasonably higher earthquake magnitude, i.e., $M \geq 5$ since the style of deformations imply complete reorganisation of cohesive laminae in the ductile to brittle form. Similar or a lesser magnitude $(M \leq 5)$ earthquake might have caused deformations at RSMS and Chamunda Devi sections since the presence of interbedded mudstone layers might have facilitated the deformation process by getting liquefied.

\subsection{Implication towards basin tectonics}

Commonly, palaeoseismologists tend to ignore the importance of SSDs with reference to basin tectonics/palaeoslope, lest they blur the distinction between auto- and allogenic products (Sims 1975; Vittori et al. 1991). However, instances are also available where studies have utilised earthquakegenerated SSDs as an advantage to the inferences from depositional tectonics and basin configuration (Bose et al. 1997). The stratigraphic distribution of SSDs within the Bilara succession demands mention in this regard that helped us to infer a broad tectonic backdrop in the course of the Bilara sedimentation. Whereas SSD structures, viz., intrastriatal fractures with downslope laminae offset, convergence of fractures with small-scale graben geometry, fluidisation and load structures dominate the lower part of the BL succession exposed at the Chamunda Devi section, disharmonic folds and low-angle thrusts represent SSD structures in the Gopa section at the upper part.

Basu and Bickford (2014) argued for $\sim 150 \mathrm{Ma}$ sedimentation history in the Marwar basin ranging between 700 and $520 \mathrm{Ma}$ on the basis of the occurrence of the $541 \mathrm{Ma}$ old detrital zircon grain reported by McKenzie et al. (2011) from sandstone in the uppermost part of the Marwar succession. Pradhan et al. (2010), on the basis of palaeomagnetic studies of coeval MIS, India and Mundine Well dyke swarms of Australia-Mawson continental blocks, argued against a single coherent entity of East Gondwana (Powell et al. 1993; Yoshida et al. 2003) by the end of the Mesoproterozoic era. Instead, a multiphase amalgamation of various cratonic blocks is proposed through a series 
of orogenic events between 750 and $530 \mathrm{Ma}$ (Meert and Van der Voo 1997; Meert 2003; Pradhan et al. 2010). The abundance of earthquake-related SSDs indicates that earthquakes must have been triggered frequently by orogenic movements along the craton margin during the deposition of the Bilara limestone. Folding, sediment injection, loading, laminae shrading, etc., suggest shortening and extension in semiconsolidated Bilara carbonates in the course of sedimentation.

\section{Conclusion}

The Bilara limestone formation, a shallow marine carbonate platform, records SSD features of widely varying geometry from three different stratigraphic levels through the succession. Separated by underformed strata, the deformed layers traceable on the outcrop scale over hundreds of metres are interpreted as products of seismic shacking. Fluidisation and liquefaction played a major role in their genesis, suggesting exposure to shock waves. SSD structures triggered by jerks are formed at various rheological states, viz., plastic, brittle and liquefied are recorded. In the absence of any marker horizon, we could not correlate the deformed layers.

Early lithification in algal laminated limestone and alteration between carbonate and mudstone shaped the deformation process either by the localised enhancement of fluid pressure or by the liquefaction of mudstone. From a varied nature of SSD structures, viz., fold, thrust, loading, laminae shrading, etc., and their stratigraphic disposition, it is inferred that the basin stress regime in the course of Bilara sedimentation changed from extension to compression. It may not be a far-fetched idea to suggest that seismogenic deformations recorded in the Bilara formation as time-correlative with the SSD horizons described from the geological sections of China, Siberia and Iberia across Precambrian-Cambrian transition. Furthermore, the documentation of semi-chaotic ordering of the Bilara succession because of recurrent penecontemporaneous deformation warrants serious caution for chemostratigraphic profiling of this succession through the Precambrian-Cambrian boundary, if not impossible.

\section{Acknowledgements}

The first and third authors acknowledge the Department of Science and Technology, Govt. of
India for extending financial help to carry out this work. The second author thanks the Department of Geology, University of Delhi and Geological Survey of India for facilitating this work.

\section{References}

Allen J R L 1982 Sedimentary structures, Vol. II; Developments in sedimentology, Vol. 30B, Elsevier, Amsterdam, 663p.

Alsop G I and Marco S 2013 Seismogenic slump folds formed by gravity-driven tectonics down a negligible subaqueous slope; Tectonophysics 605 48-69.

Ansari A H, Pandey K, Sharma M, Agrawal S and Kumar Y 2018 Carbon and oxygen isotope stratigraphy of the Ediacaran Bilara group, Marwar supergroup, India: Evidence for high amplitude carbon isotopic negative excursions; Precamb. Res. 308 75-91.

Basu A and Bickford M E 2014 Contributions of zircon U-Pb geochronology to understanding the volcanic and sedimentary history of some Purāna basins, India; J. Asian Earth Sci. 91 252-262.

Bose P K, Banerjee S and Sarkar S 1997 Slope-controlled seismic deformation and tectonic framework of deposition, Koldaha Shale, India; Tectonophysics 2691 51-169.

Chakraborty P P 2011 Slides, soft-sediment deformations, and mass flows from Proterozoic Lakheri limestone formation, Vindhyan supergroup, central India, and their implications towards basin tectonics; Facies $\mathbf{5 7}(\mathbf{2})$ 331-347.

Chauhan D S 1999 Tectonic and sedimentary evolution of the Marwar basin: A Neoproterozoic-early Cambrian intracratonic sag basin; In: Proceedings of the seminar on geology of Rajasthan - Status and perspective (ed.) Kataria P (A.B. Roy Felicitation Volume), Geology Department, MLSU, Udaipur, pp. $111-125$.

Chauhan D S, Ram B and Ram N 2004 Jodhpur sandstone: A gift of ancient beaches to western Rajasthan; J. Geol. Soc. India 64 265-276.

Chen J, Van Loon A J, Han Z and Chough S K 2009 Funnel-shaped, breccia-filled clastic dykes in the late Cambrian Chaomidian formation (Shandong Province, China); Sedim. Geol. 221 1-6.

Coniglio M 1986 Synsedimentary submarine slope failure and tectonic deformation in deep-water carbonates, Cow Head group, western Newfoundland; Can. J. Earth Sci. 23(4) 476-490.

Dechen S and Aiping S 2012 Typical earthquake-induced soft-sediment deformation structures in the Mesoproterozoic Wumishan formation, Yongding river valley, Beijing, China and interpreted earthquake frequency; J. Palaeogeogr. 1(1) 71-89.

Dill R F, Eugene A, Anthony S T, Jones K K and Randolph P S 1986 Giant subtidal stromatolites forming in normal salinity waters; Nature 324 55-58.

Elliot C G and Williams P F 1988 Sediment slump structures: A review of diagnostic criteria and application to an example from Newfoundland; J. Struct. Geol. 10 $171-182$. 
Erickson S G, Strayer L M and Suppe J 2001 Initiation and reactivation of faults during movement over thrust-fault ramp: Numerical mechanical models; J. Struct. Geol. 23 $11-23$.

Ettensohn F R and Kulp M A 1995 Structural-tectonic control on middle-late ordovician deposition of the Lexington limestone, Central Kentucky; In: Ordovician odyssey: Short papers for the seventh international symposium on the Ordovician system: SEPM (Society for Sediment Geol) (eds) Cooper J D, Droser M L and Finney S C, Pacific Section, Fullerton, California, pp. 261-264.

Ettensohn F R, Rast N and Brett C E 2002 Ancient seismites; Geol. Soc. Am. Spec. Paper 190 359p.

Ettensohn F R, Johnson W K, Hickman J B and Kuhnhenn G L 2002b Intermediate- ramp, shallow open-marine carbonates: Tempestites and seismites in the Grier member, Lexington limestone; In: Impact of geology and human history at Camp Nelson and Perryville, central Kentucky (eds) Andrews W M Jr, Ettensohn F R, Gooding P J and Smath M L, Kentucky Society of Professional Geologists Annual Field Trip; Kentucky Society of Professional Geologists, Lexington, pp. 76-83.

Ettensohn R, Zhang C, Gao L and Lierman R T 2011 Soft-sediment deformation in epicontinental carbonates as evidence of paleoseismicity with evidence for a possible new seismogenic indicator: Accordion folds; Sedim. Geol. 235 222-233.

Evans P J and Bradbury K K 2007 Fractured dirt: Deformation textures and processes in sediment and other unconsolidated deposits; J. Geol. 35(7) 671-672.

Garcia-Tortosa F J, Alfaro P, Gibert L and Scott G 2011 Seismically induced slump on an extremely gentle slope (b1) of the Pleistocene Tecopapaleo lake (California); Geology 39 1055-1058.

Gregory L C, Meert J G, Bingen B, Pandit M K and Torsvik T H 2009 Paleomagnetism and geochronology of the Malani igneous suite, Northwest India: Implications for the configuration of Rodinia and the assembly of Gondwana; Precamb. Res. 170 13-26.

Grimm K A and Orange D L 1997 Synsedimentary fracturing, fluid migration, and subaqueous mass wasting: Intrastriatal-microfractured zones in laminated diatomaceous sediments, Miocene Monterey formation, California, USA; J. Sedim. Res. 67 601-613.

Grotzinger J P 1986 Evolution of early Proterozoic passivemargin carbonate platform, Rocknest formation, WopmayOrogen, N. W.T., Canada; J. Sedim. Petrol. 56 831-847.

Grotzinger J P 1989 Facies and evolution of Precambrian carbonate depositional systems: Emergence of the modern platform archetype; In: Controls on carbonate platform and basin development, Vol. 44, SEPM Special Publication, Arizona 44 pp. 79-106.

Hamon Y and Merzeraud G 2008 Facies architecture and cyclicity in a mosaic carbonate platform: Effects of faultblock tectonics (Lower Lias, Causses platform, southeast France); Sedimentology 55(1) 155-178.

Hempton M R and Dewey J S 1983 Earthquake-induced deformational structures in young lacustrine sediments, East Anatolian fault, southeast Turkey; Tectonophysics 98 14-17.
Heubeck C, Ergaliev G and Evseev S 2013 Largescale seismogenic deformation of a carbonate platform straddling the Precambrian-Cambrian Boundary, Karatau Range, Kazakhstan; J. Sedim. Res. $\mathbf{8 3}$ 1005-1025.

Hobbs B E, Means W D and Williams P F 1976 An outline of structural geology; John Wiley, New York, 571p.

Hoffman P 1976 Stromatolite morphogenesis in Shark Bay, Western Australia; Dev. Sedimentol. 20 261-271.

Holzer T L, Youd T L and Hanks T C 1989 Dynamics of liquefaction during the 1987 Superstition Hills California earthquake; Science 244 59-69.

James N P and Jones B 2016 Origin of carbonate sedimentary rocks; American Geophysical Union, Washington D.C, Wiley, 446p.

Jewell H E and Ettensohn F R 2004 An ancient seismite response to Taconian far-field forces: The cane Run Bed, upper Ordovician (Trenton) Lexington limestone, Central Kentucky (USA); J. Geodyn. 37 487-511.

Jones M E and Preston R M E 1987 Deformation of sediments and sedimentary rocks; Geol. Soc. London Spec. Publ. 33629.

Kumar S and Pandey S K 2008 Discovery of trilobite trace fossils from the Nagaur Sandstone, the Marwar Supergroup, Bikaner District, Rajasthan; Curr. Sci. 94(8) 1081-1084.

Lowe D R 1975 Water escape structures in coarse grained sediments; Sedimentology 22 157-204.

Maltman A 1994 Prelithification deformation; In: Continental deformation (ed.) Hancock P L, Pergamon Press, Oxford, pp. 143-158.

Marco S Paleomagnetism and paleoseismology in the late Pleistocene Dead Sea graben; PhD Thesis, The Hebrew University of Jerusalem, 1996, 95p.

Marco S and Agnon A 1995 Prehistoric earthquake deformations near Masada, Dead Sea graben; Geology 23 695-698.

McKenzie N R, Hughes N C, Myrow P M, Xiao S and Sharma M 2011 Correlation of Precambrian-Cambrian sedimentary successions across northern India and the utility of isotopic signatures of Himalayan lithotectonic zones; Earth Planet. Sci. Lett. 312 471-483.

Meert J G 2003 A synopsis of events related to the assembly of eastern Gondwana; Tectonophysics 362 1-40.

Meert J G and Van der Voo R 1997 The assembly of Gondwana 800-550 Ma; J. Geodyn. 23 223-235.

Meert J G, Pandit M K, Pradhan V R, Banks J C, Sirianni R, Stroud M, Newstead B and Gifford J 2010 The Precambrian tectonic evolution of India: A 3.0 billion year odyssey; J. Asian Earth Sci. 39 483-515.

Montenat C, Barrier P, Ottd'Estevou P and Hibsch C 2007 Seismites: An attempt at critical analysis and classification; Sedim. Geol. 196 5-30.

Obermeier E, Pond S and Olson R 2002 Green Paleoliquefaction studies in continental settings; Geol. Soc. Am. Spec. Paper 359 13-27.

Obermeier S, Martin J R, Frankel A D, Youd T L, Munson P J, Munson C A and Pond E L 1993 Liquefaction evidence for one or more strong Holocene earthquakes in the Wabash Valley of Southern Indiana and Illinois, with a preliminary estimate of magnitude; United States Geological Survey Professional Paper 1536, 27p. 
Owen G 2003 Load structures: Gravity-driven sediment mobilization in the shallow subsurface; In: Subsurface sediment mobilization (eds.) Van Rensbergen P, Hillis R R, Maltman A J and Morley C K, J. Geol. Soc. London Spec. Publ. 216 21-34.

Owen G and Moretti M 2011 Identifying triggers for liquefaction-induced soft-sediment deformation in sands; Sedim. Geol. 235 141-147.

Owen G, Moretti M and Alfaro P 2011 Recognizing triggers for soft-sediment deformation: current understanding and future directions; Sedim. Geol. 235 133-140.

Pandey D K and Bahadur T 2009 A review of the stratigraphy of Marwar Supergroup of west-central Rajasthan; $J$. Geol. Soc. India 73 747-758.

Pareek H S 1984 Pre-Quaternary geology and mineral resources of northwestern Rajasthan (Memoirs of the Geological Survey of India, No. 115), Geological Survey of India, Calcutta, pp. 1-99.

Peacock D C P and Sanderson D J 1992 Effects of layering and anisotropy on fault geometry; J. Geol. Soc. London $149793-802$.

Powell C McA, McElhinny M W, Meert J G and Park J K 1993 Paleomagnetic constraints on timing of the Neoproterozoic break-up of Rodinia and the Cambrian formation of Gondwana; Geology 21 889-892.

Pradhan V R, Meert J G, Pandit M K, Kamenov G, Gregory L C and Malone S J 2010 India's changing place in global Proterozoic reconstructions: A review of geochronologic constraints and paleomagnetic poles from the Dharwar, Bundelkhand and Marwar cratons; J. Geodyn. 50 224-242.

Pratt B R, James N P and Cowan C A 1992 Peritidal carbonates; In: Facies models: Response to sea level change (eds) Walker R G and James N P, Geological Association of Canada, St. John's, Newfoundland, pp. 303-322.

Reiter L 1990 Earthquake hazard analysis, issues and insights; Columbia University Press, New York, 254p.

Ricci Lucchi F 1995 Sedimentological indicators of paleoseismicity; In: Perspectives in paleoseismology (eds) Serva L and Slemmons D B, Assoc. Engn. Geol. 6 7-17.

Ringrose P S 1989 Palaeoseismic liquefaction event in late Quaternary lake sediment at Glen Roy, Scotland; Terra Nova 1 57-62.

Rodríguez-Pascua M A, Calvo J P, De Vicente G and Gómez-Gras D 2000 Soft-sediment deformation structures interpreted as seismites in lacustrine sediments of the Prebetic zone, SE Spain, and their potential use as indicators of earthquake magnitudes during the late Miocene; Sedim. Geol. 135 117-135.

Samanta P, Mukhopadhyay S, Mondal A and Sarkar S 2011 Microbial mat structures in profile: The Neoproterozoic Sonia sandstone, Rajasthan, India; J. Asian Earth Sci. 40 542-549.

Sarkar S and Bose P K 1992 Variations in late Proterozoic stromatolites over a transition from basin plain to nearshore subtidal zone; Precamb. Res. 56(1-2) 139-157.

Sarkar S, Banerjee S and Chakraborty S 1995 Synsedimentary seismic signature in Mesoproterozoic Koldaha Shale,
Kheinjua formation, central India; Indian J. Earth Sci. 22 158-164.

Sarkar S, Chakraborty P P and Bose P K 1996 Proterozoic Lakheri limestone, central India: Facies, paleogeography and physiography; In: Recent advances in vindhyan geology (ed.) Bhattacharya A, J. Geol. Soc. India Memoir 36 $5-25$.

Sarkar S, Choudhuri A, Banerjee S, Van Loon A J (Tom) and Bose P K 2014 Seismic and non-seismic soft-sediment deformation structures in the Proterozoic Bhander limestone, central India; Geologos 20 89-103.

Sarkar S, Chakraborty P P and Bose P K 1994 Multimode generation of carbonate tabular intraclast deposits: unnamed Proterozoic formation, Maharastra; J. Geol. Soc. Ind. 4 415-423.

Seilacher A 1969 Fault-graded beds interpreted as seismites; Sedimentology 13 155-159.

Shrivatava B P 1992 Significance of fourth dimensional stratigraphic makers in Paleozoic sediments of West Central Rajasthan: Palaeogeographic implications, Petroleum habitat; Indian J. Petrol. Geol. 1(2) 224-244.

Sims J D 1975 Determining earthquake recurrence intervals from deformational structures in young lacustrine sediments; Tectonophysics 29 141-152.

Spence G H and Tucker M E 1997 Genesis of limestone megabreccias and their significance in carbonate sequence stratigraphic models: A review; Sedim. Geol. 112 163-193.

Strachan L J 2002 Slump-initiated and controlled syndepositional sandstone remobilization; an example from the Namurian of County Clare, Ireland; Sedimentology 49 $25-41$.

Torsvik T H, Carter L, Ashwal L D, Bhushan S K, Pandit M K and Jamtveit B 2001 Rodinia refined or obscured: Paleomagnetism of the Malani igneous suite (NW India); Precamb. Res. 108 319-333.

Van Loon A J 1992 The recognition of soft-sediment deformations as early-diagenetic features - A literature review; In: (Diagenesis, III) developments in sedimentology (eds) Chilingarian G V and Wolf K H, Vol. 47, Elsevier, Amsterdam, pp. 135-189.

Vittori E, Lebini S S and Gewa L 1991 Paleoseismology - A state-of-the art; Tectonophysics 19 39-32.

Wheeler R L 2002 Distinguishing seismic from nonseismic soft-sediment structures: Criteria from seismic-hazard analysis; In: Ancient seismites (eds) Ettensohn F R, Rast $\mathrm{N}$ and Brett C E, Geol. Soc. Am. Spec. Paper 359 $1-11$.

Wilks M E The geology of the Steep rock group, N.W. Ontario: A major Archean unconformity and Archean stromatolites; Un-published MSc Thesis, University of Saskatchewan, 1986, 206p.

Yoshida M, Santosh M and Rajesh H M 2003 Role of PanAfrican events in the circum-East Antarctic orogen of East Gondwana: A critical overview; In: Proterozoic East Gondwana: Supercontinent assembly and breakup (eds) Yoshida M, Windley B F and Dasgupta S, J. Geol. Soc. London Spec. Publ. 206 57-75. 